\title{
The Discount Rate and Market Interest Rates: Theory and Evidence
}

\author{
Daniel L. Thornton
}

HE relationship between the Federal Reserve's discount rate and money market interest rates continues to be a topic of much interest and even more confusion. A significant number of money market analysts and some in public service believe that the discount rate is an important tool through which the Federal Reserve exerts its influence over the economy - particularly market interest rates. This view appears to have gathered strength from recent evidence that discount rate changes have a statistically significant effect on market interest rates and from the presumed effects of a 1982 change in the Federal Reserve's operating procedure.' Consequently, the long-standing discrepancy between what economic theory says about the relationship between the discount rate and maket interest rates and the view among many money market analysts appears to have become larger. The purpose of this article is to narrow the gap by pointing out that, both in theory and in practice, changes in the Federal Reserve's discount rate, per se, have essentially no effect on maket interest rates. At best they "signal" changes in the Federal Reserve's use of other more powerful tools of policy. Any impact of a discount rate change on market interest rates is due to changing expectations or to a change in Federal Reserve operations following the discount rate change.

Daniel $L$. Thornton is a senior economist at the Federal Reserve Bank of Sf. Louis. Rosemarie Mueller provided research assistance.

See Thornton (1982) for a summary of some of the usual sources of confusion; Thornton (1982), Sellon and Seibert (1982) and Smirlock and Yawitz (1985) for empirical estimates of a change in the discount rate on market interest rates; and Batten and Thomton (1984, 1985) and Hakkio and Pearce (1986) for empirical estimates of an impact of a discount rate change on the foreign exchange market.

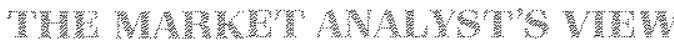

Figure 1 illustrates a commonly held view of the relationship between a cut in the discount rate and the response of market interest rates; it shows the hypothetical time path of market interest rates before and after a hypothetical cut in the Federal Reserve discount rate at time $t_{0}$ and it reflects the perception that a cut in the discount rate causes market interest rates to be permanently lower than they otherwise would have been. This cause-and-efect relationship is purely qualitative. It is not chear whether a 1 percentage-point cut in the discount rate will lower market rates by 1 percentage point or only a few basis points. It merely is asserted that market rates will be lower.

The view that the discount rate is preeminent in the money market contrasts shaply with economic theory and the perception of many economists that the discount rate is the least powerful of the Federat Reserve's tools for influencing the money stock and interest rates. Before tuning to this analysis in detail, it is instructive to consider some casual evidence against the idea that the discount rate is preominent in the money market. Chart 1 shows the three-month Treasury bill, federal funds and discount rates weekly for the period from October 1982 to June 1986. What do these data show about the effect of a discount mate change on maket interest rates? First, in a number of instances, discount rate changes are followed closely by a leveling ofl of market interest rates of by a movement in the opposite direction. While this does not fule out the possibility that market rates would have been higher lower if the discount rate had not been cut raised, it does suggest that the market analyst 
view is not supported by a simple analysis of inferest rate behavior.

Second, nearly all discount rate changes follow, ather than lead, movements in matel interest rates in the same direction. It would seem that changes in market interest rates motivate discount rate changes rather than the reverse. Furthermore, even when market rates declined (increased) following a discount rate cut (increase), it is particularly difficult to determine whether market lates would have moved in the same or similar lashion in the absence of a change in the discount rate. While all of this is inconclusive, it provides weak and often contrary evidence of a discount rate/market interest rate line of causation, and provides little comfort to those who believe the view illustrated by figure 1

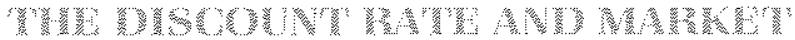

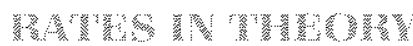

Because the interest rate is the price of credit, any impact of discount rate changes on market interest rates must come via their effect on the supply of or the demand for credit. In this regard, three distinct though not necessarily mutualy exchusive - effects of a discount rate change can be identified. These are illustrated in figure 2. Prior to the discount rate cut, the credit maket is in equilbrium at an interest rate of $R_{i p}$ corresponding to the intersection of the initial supply and demand curves, $\mathrm{S}_{4)}$ and $\mathrm{D}_{0}$, respectively.

\section{wher}

The frst effect, called the direct for substitution effect, causes a shift in the supply of credit. Discount window borrowing is one method depository institutions use to adjust their reserve position. Alternatively, they can buy federal funds or sell govenment securities directly in the money marke. "Since these alternatives are close substitutes, the demand for borrowed reserves depends on the spread between market inlerest rates, especially the fedeal funds rate, and the discount rate. As the federal funds-discount rate spread mereases, borrowings from the fedemal heseve rend to increase and vice versa. Thus, the level of discomnt window borrowings usually is expressed as:

(1) $\operatorname{Bor}=\alpha\left(R_{\mathrm{r}}-\mathbf{R}_{\mathrm{k}}\right), \quad \alpha>0$,

2This is true of other periods as well; see Thornton (1982), p. 14.

Depository institutions also can call in loans or cary the deficiency over into the next reseve period. They rarely, if ever, use these alternatives, however.
Figure 1

Hypothefical Response to a Disconnl Rate Cut

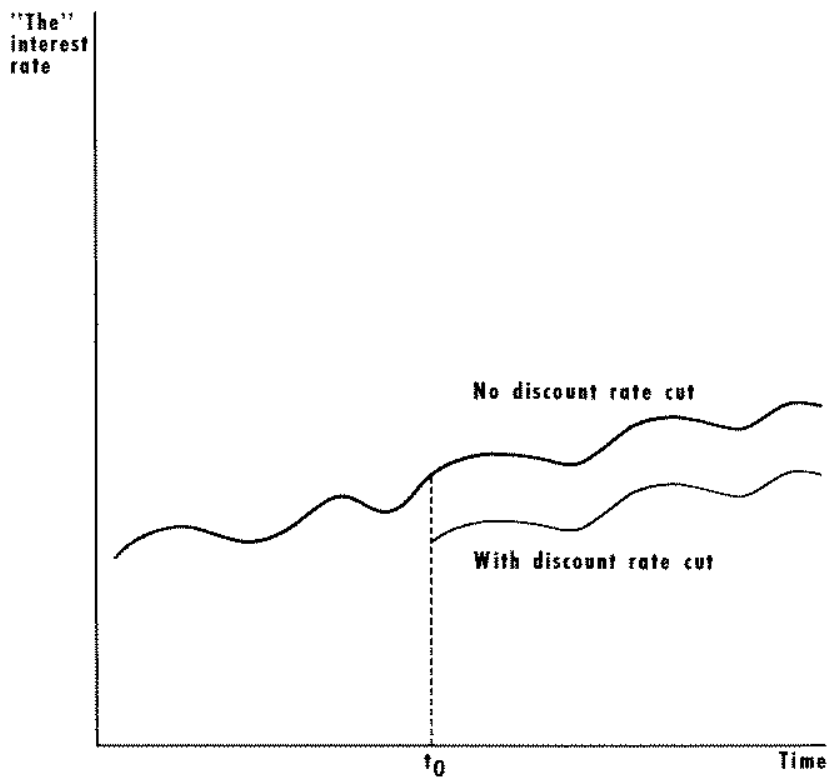

2.

where Bort denotes the aggregate level of indebtedness of depository institutions to the Federal Reserve and $R_{t}$ and $R_{d}$ denote the fedenal funds and discount rate, respectively

To illustrate the direct effect of a change in the discount rate on market interest lates, assume that the discount rate is cut. In response, depository instituflons increase their borrowings and reduce their use of alternative sonrces of reserves. The increase in bomowings produces an increase in the monetary base and, in tum, the supply of credit - illustrated in flgure 2 by a shifh fom $\mathrm{S}_{0}$ to $\mathrm{S}_{1}$. Thus, a discound ate cul has a direct oflect, causing market interest rates to decline from $R_{0}$ to $R_{1}$. The effect of an increase in the discount rate would be symmetric.

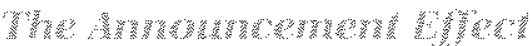

Additionally, discount rate changes can have an "announcement effect." If a change in the discount rate is interpreted as a "signal" that the Federal Reserve will alter its policy with respect to the growh of reserves and the money stock, the market may react in anticipalion of a policy change. A cut in the discount rate usually is thought to be a signal that the Federal Reserve is going to pursue an easier monelay policy so the maket reacts in anticipation of Federal Reserve 
Chart

\section{Selected Interest Rates}

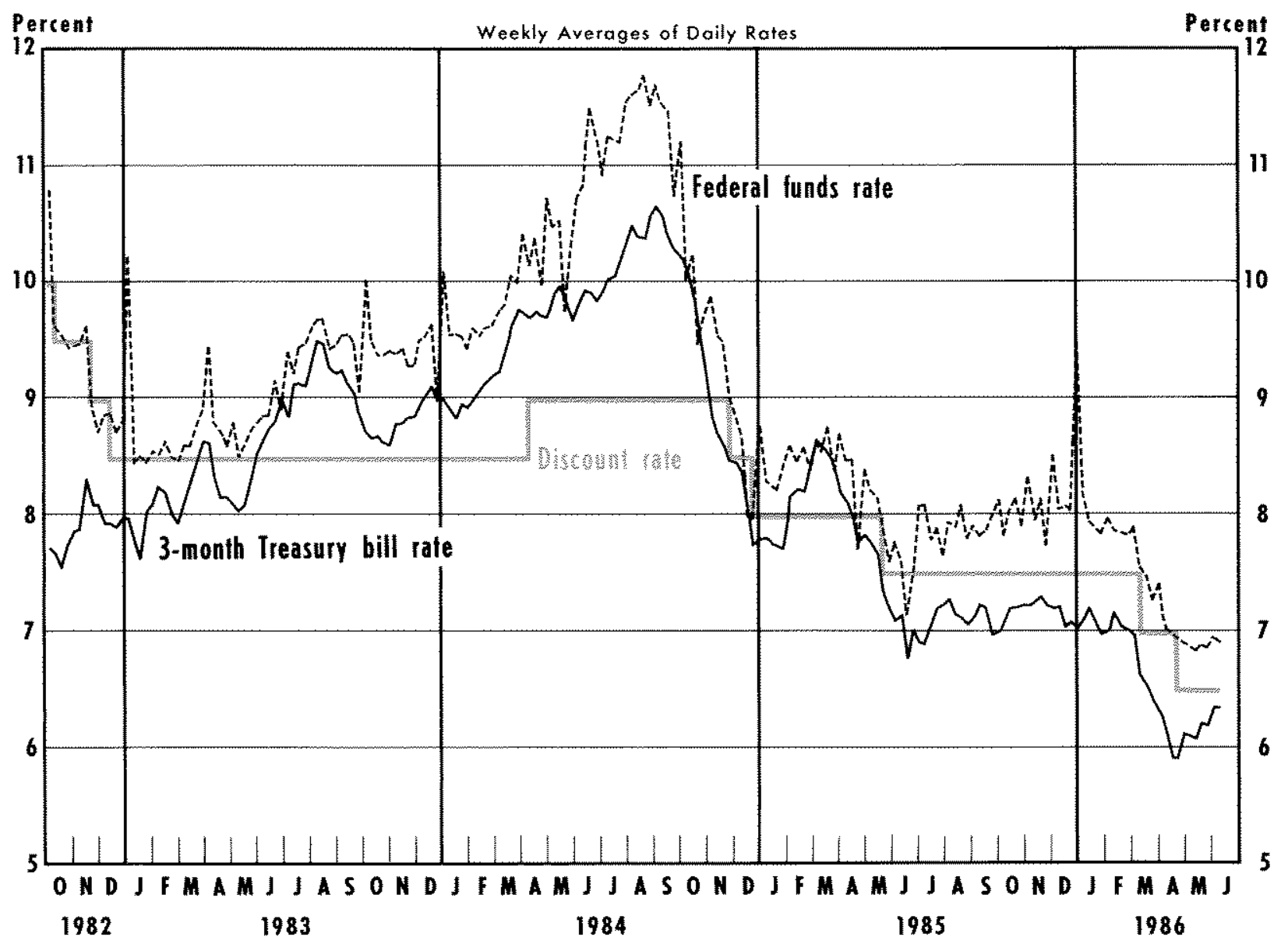

open market operations that will increase the supply of credit. Consequenty, there is an immediate shift in the supply of credit, relative to demand, in anticipation of futher monetary ease. If the announcement effect occurs, it is over and above the direct effect of a discount rate change, and is illustrated by the shift from $S_{1}$ to $S_{2}$ in figure $2 . "$

\section{Whan}

Finally, there could be a "policy effect" if the Federat Reserve actually changes its policy and increases the

4This is not the only possible interpretation for the market. See Batten and Thornton (1984) and Smith (1963) for a discussion of this point.

5 This also coutd have been illustrated by a reduction in the demand for credit, but was illustrated as a shift in supply to keep the figure simple. growth rate of reserves. This also can be illustrated by the shift from $S_{0 k}$ to $S_{1}$. If the market correctly anticipates the direction and magnitude of the policy effect, market interest rates will remain permanently lower at $\mathbf{R}_{2}$. Of course, this requires that the market's expectations be correct, both in terms of the actual change in Federal Reserve policy and in terms of the impact of that policy change on the market." As the Federal Reserve purchases more securities, speculators sell off those acquired in anticipation of the policy change. If the market overanticipates Federal Reserve actions, however, market rates first will fall below and then

"This brief discussion gives rise to several issues not analyzed in this paper, such as the effectiveness of poficy and the credibility of the central bank. For a general discussion of the credibility issue, see Cukierman (1986). 
subsequently rise to their long-run equilibrium. Furthermore, if the market's expectations are incorrect and Federal Reserve policy remains unchanged, interest rates will rise back to $\mathrm{R}_{\mathrm{s}}$ - the only impact of a discount rate change would be the direct effect.

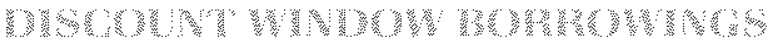

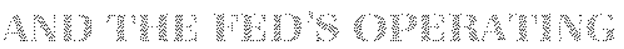

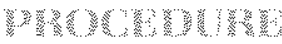

Some have argued that the policy effect has become more important since the October 1982 change in the Federal Reserve's operating procedure. At that time, the Board switched from a nonborrowed reserve to a borrowed reserve operating procedure. It is now widely believed that the Federal Reserve operates to achieve a certain average level of botrowed reserves (called the initial borrowing assumption) over a given time period: The mechanics of this operating procedure can be illustrated by tracing the reaction of the Federal Reserve to an unexpected increase in the demand for reserves. Other things unchanged, an in crease in the demand for reserves tends to cause both borrowings and the funds rate to rise, as depository institutions atlempt to satisly their demand for reserves in the money market and at the Federal Reserve discount window. As borrowings increase relative to the borrowing assumption, the Fed increases the supply of nonborrowed reserves via open market purchases of goveroment securities; in response, both borrowing and the federal funds rate fall.

A cut in the discount rate, not accompanied by a change in the intial borrowing assumption, works analogously. If the federal Reserve cuts the discount rate, the demand for borrowed reserves will increase at all levels of the federal funds rate, causing borrowings to increase relative to the initial borrowing assumption. If the initial borrowing assumption is unchanged, the fed must increase the supply of nonborrowed reserves through open market operations until the federal funds rate has declined by enough to return borrowings to the level of the borrowing assumption.

The above implies that equation 1 can be written as:

(2) Borr $^{*}=\alpha\left(\mathbf{R}_{i}-\mathbf{R}_{d}\right)$,

where Borr* denotes the Federal Reserve's initial borrowing assumption. Equation 2 implies a constant spread between the federal funds and discount rates.

'For a discussion of this, see Roley (1986), Wallich (1984) and Federal Reserve Bank of New York (1986).

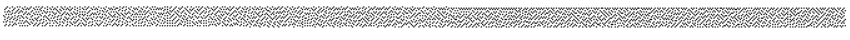

Figure ?

Three Possible Eflects of a Discount Rate Cut on Matkel Inferest Rates

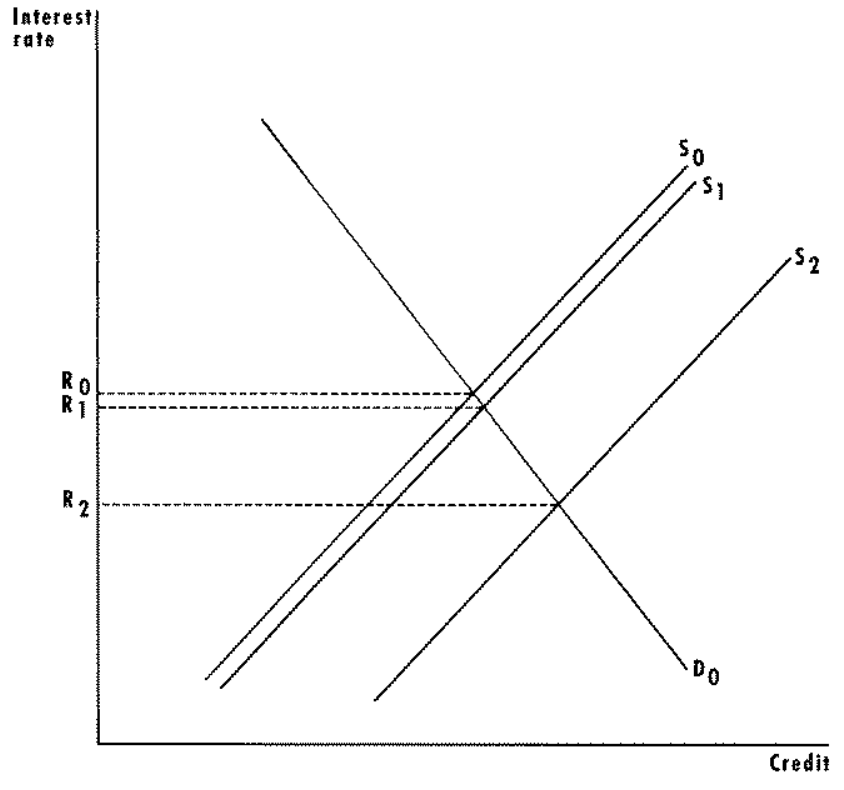

Any change in the discount rate will be matched by an equal change in the federal funds rate, providing there is no compensatory change in the bonowing assumption.

It should be emphasized that it is not the discount rate change per se that affects market interest mates, but the subsequent policy effect if the Federal Reserve strictly adheres to an operating procedure that attempts to maintain the level of borrowings assumed by its cument policy directive. If the market perceives this behavior, it could also strengthen any announcement effect.

\section{W}

All of the potential effects of a change in the discount ate on market interest rates (but, in particular, the policy effect) depend on the so-called "liquidity effect" - the change in interest rates associated with an unanticipated increase in the growth rate of the money supply. While such an effect is widely touted in theorelical discussions, there is little empirical evi dence to support it. Yet, without a liquidity effect or at least the expectation of a liquidity effect, changes in the discount rate could not have an impact on a broad spectrum of market interest rates.

8This, of course, ighores the possible effect of changes in expectathons of inflation on interest rates. See Brown and Santori (1983), Cagan and Gandolfi (1969) and Melvin (1983) for a review of the direct evidence on the liquidity effect. 


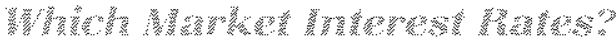

Much of the discussion thus far has been carried out in terms of the federal funds rate. In reality, there are a large number of different rates: the rates on federal funds, Treasury bills, notes and bonds, commercial bank loans, mortgages, etc. Hence, the array of credit market assets should be divided into those that are closely related to the discount rate and those that are less closely related to it.

The market for federal funds is one segment of the credit market that is particularly sensitive to discount rate changes and to changes in Federal Reserve operations. Federal funds are simply the reserve assets of one depository institution that are sold (lent) to another for the purpose of achieving both institutions' desired reserve positions. Because such funds are close substitutes for reserves supplied by the Federal Reserve, including those supplied through the discount window, changes in the discount rate or Federal Reserve policy should initially affect the federal funds rate and subsequently other market rates. ISee page 10 for a discussion of the relationship between the discount rate and the prime rate.

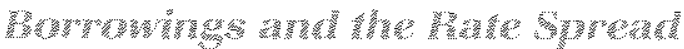

The relationship between the discount rate and market interest rates rests, in one way or another, on the strength of the relationship between borrowings and the rate spread. Equations 1 and 2 , however, imply that borrowings depend on more than the spread between the market and discount rates. To see this, assume that there are no impediments to borrowing so that depository institutions can borrow any amount they desire at the discount window. If this were the case, borrowings would rise whenever market rates were above the discount rate and fall whenever the discount mate is above the market rate. If we abstract from problems of inflation and inflationary expectations, the market rate would always equal the discount rate." But if $\mathbf{R}_{f}=R_{i}$, however, equation 1 implies that borrowings would be zero.

The data in chart 2 , which show weekly adjustment borrowings and the federal funds rate/discount rate

\footnotetext{
IUnder this arrangement, one can envision the Federal Reserve pushing down interest rates by lowering the discount rate. As this is done, however, money growth will accelerate and so will inflation. As a result, nominal interest rates will rise and money will grow even taster. Hence, even if the discount window were completely "open," the Federal Reserve would be unable to control interest rates with the discount rate in anything but the short tun.
}

spread from October 1982 to June 1986, indicate that the discount and federal funds rates are seldom equal." Moreover, when the rates are equal, borrowings are not zero. This is prima facie evidence that borrowing is not explained solely by the interest rate spread. Indeed, Federal Reserve regulations, which set forth the conditions under which depository institutions may use the discount window, make it clear that borrowing is a privilege and explicitly state that it is inappropriate to borrow "to take advantage of a differential between the discount rate and the rate on alternative sources of funds." 11

A visual inspection of chart 2 shows that there is usually a positive relationship between borrowings and the rate spread, that is, that increases in borrowings tend to be associated with increases in the spread and vice versa. There are, however, some marked departures from this relationship. The most obvious of these occured with the sharp increase in borrowings in May-June 1984 and November 1985. Both of these events were accompanied by special circumstances. The former is associated with heavy discount window borrowings by Continental Bank of Illinois and the latter with the largest single-day borrowing from the Federal Reserve when the Bank of New York (BONY) experienced a computer failure on November 21 , 1985. Even when these outliers are ignored, however, there are instances when borrowings and the spread move in opposite directions. Moreover, there is considerable variation in the relationship between the average level of borrowings and the average level of the spread. The most obvious of these is the period from June 13, 1984, through October 3, 1984, when the spread averaged over 200 basis points and borrowings averaged less than a billion dollars, as compared to an average spread of 70 basis points and average borrowings of $\$ .7$ billion over the entire period.":

The strength of the relationship between borrow-

\footnotetext{
${ }^{10}$ Borrowing from the Federal Reserve is divided into three categories: adjustment botrowing, seasonal borrowing and extended credit borrowing. The borrowing assumption, however, pertains only to adjustment and seasonal borrowings; see Partian, Hamdani and Camilli (1986).

"This is called the "reluctance of banks to borrow from the Federal Reserve," and at one time there was considerable discussion over whether this reluctance was "inherent" or "induced."

isee Federal Reserve Bank of New York (1986) for a discussion of the BONY borrowings.

iIt could be that depository institutions became more reluctant to borrow from the Federal Reserve in light of the large borrowings by Contmental Bank.
} 


\section{The Discount Rate and the Prime Rate}

One possible reason for the hypothesized strong effects of discount rate changes on interest rates is the fact that discount rate changes and changes in the commercial bank prime ate often occur tom gether and are usually accompanied by a great deal of publicity. Both of these rates are administered rates that do not change daily with market forces, but change less frequently and by fairly large amounts.

Because changes in the prime rate often follow on the heels of changes in the discount ate, it may lead some to conclude incorrecty the latter caused the former. Because both are administered rates, however, they are likely to tespond similarly but not precisely cotemmously, to market rates. for example, as market interest rates fall relative to these administered rates, these rates become increas ingly out of lne with the market Hence, there is an incentive for the Federal Reserve to cut the discount rate and for commercial banks to cut their prime rate, If the Federal Reseve cuts the discount rate first, banks may feel additional pressure to cut their prime rate, but this does not imply that the former caused the latter. Rather both rates are merely responding to market forces.

The table above shows that on four occasions since October 1982 discount rate and prime rate changes were effective on the same day. In each instance, the announcement of a cut in the prime rate followed the announcement of the discount rate change. For the remaining fve changes in the discount rate, changes in the prime rate followed discount rate changes by a week or more Also, there were a number of changes in the prime rate that were not even remotely associated with changes in the discount rate. It would appear that changes in market interest rates are primarily responsible for changes in both of these administered rates.

\begin{tabular}{|c|c|c|c|}
\hline \multicolumn{2}{|c|}{ Prime rate } & \multicolumn{2}{|c|}{ Discount rate } \\
\hline Date effective & Change & Date effective & Change \\
\hline \multirow[t]{2}{*}{ October 7,1982} & $13.5 \%$ to $13 \%$ & & \\
\hline & & October 12,1982 & $10 \%$ to $9.5 \%$ \\
\hline October 13,1982 & $13 \%$ to $12 \%$ & & \\
\hline \multirow[t]{2}{*}{ November 22,1982} & $12 \%$ to $11.5 \%$ & November 22,1982 & $9.5 \%$ to $9 \%$ \\
\hline & & December 14,1982 & $9 \%$ to $8.5 \%$ \\
\hline January 11,1983 & $11.5 \%$ to $11 \%$ & & \\
\hline February 25,1983 & $11 \%$ to $10.5 \%$ & & \\
\hline August 8,1983 & $10.5 \%$ to $11 \%$ & & \\
\hline March 19, 1984 & $11 \%$ to $11.5 \%$ & & \\
\hline \multirow[t]{2}{*}{ April 5, 1984} & $11.5 \%$ to $12 \%$ & & \\
\hline & & April 9, 1984 & $8.5 \%$ to $9 \%$ \\
\hline May 8,1984 & $12 \%$ to $12.5 \%$ & & \\
\hline June 25,1984 & $12.5 \%$ to $13 \%$ & & \\
\hline September 27,1984 & $13 \%$ to $12.75 \%$ & & \\
\hline October 16,1984 & $12.75 \%$ to $125 \%$ & & \\
\hline October 29,1984 & $12.5 \%$ to $12 \%$ & & \\
\hline \multirow[t]{2}{*}{ November $8,1984^{\circ}$} & $12 \%$ to $11.75 \%$ & $\therefore$ & \\
\hline & & November 21, 1984 & $9 \%$ to $8.5 \%$ \\
\hline November 28,1984 & $11.75 \%$ to $11.25 \%$ & & \\
\hline \multirow[t]{2}{*}{ December 19,1984} & $11.25 \%$ to $10.75 \%$ & & \\
\hline & & December 24, 1984 & $8.5 \%$ to $8 \%$ \\
\hline January 15,1985 & $10.75 \%$ to $10.5 \%$ & & \\
\hline May 20,1985 & $10.5 \%$ to $10 \%$ & May 20,1985 & $8 \%$ to $7.5 \%$ \\
\hline June 18,1985 & $10 \%$ to $9.5 \%$ & & \\
\hline March 7, 1986 & $9.5 \% 109 \%$ & March 7,1986 & $7.5 \%$ to $7 \%$ \\
\hline April 21, 1986 & $9 \%$ to $8.5 \%$ & April 21, 1986 & $7 \%$ to $6.5 \%$ \\
\hline
\end{tabular}




\section{Chart 2 \\ Adjustment plus Seasonal Borrowings from Federal Reserve and Federal Funds-Discount Rate Spread}

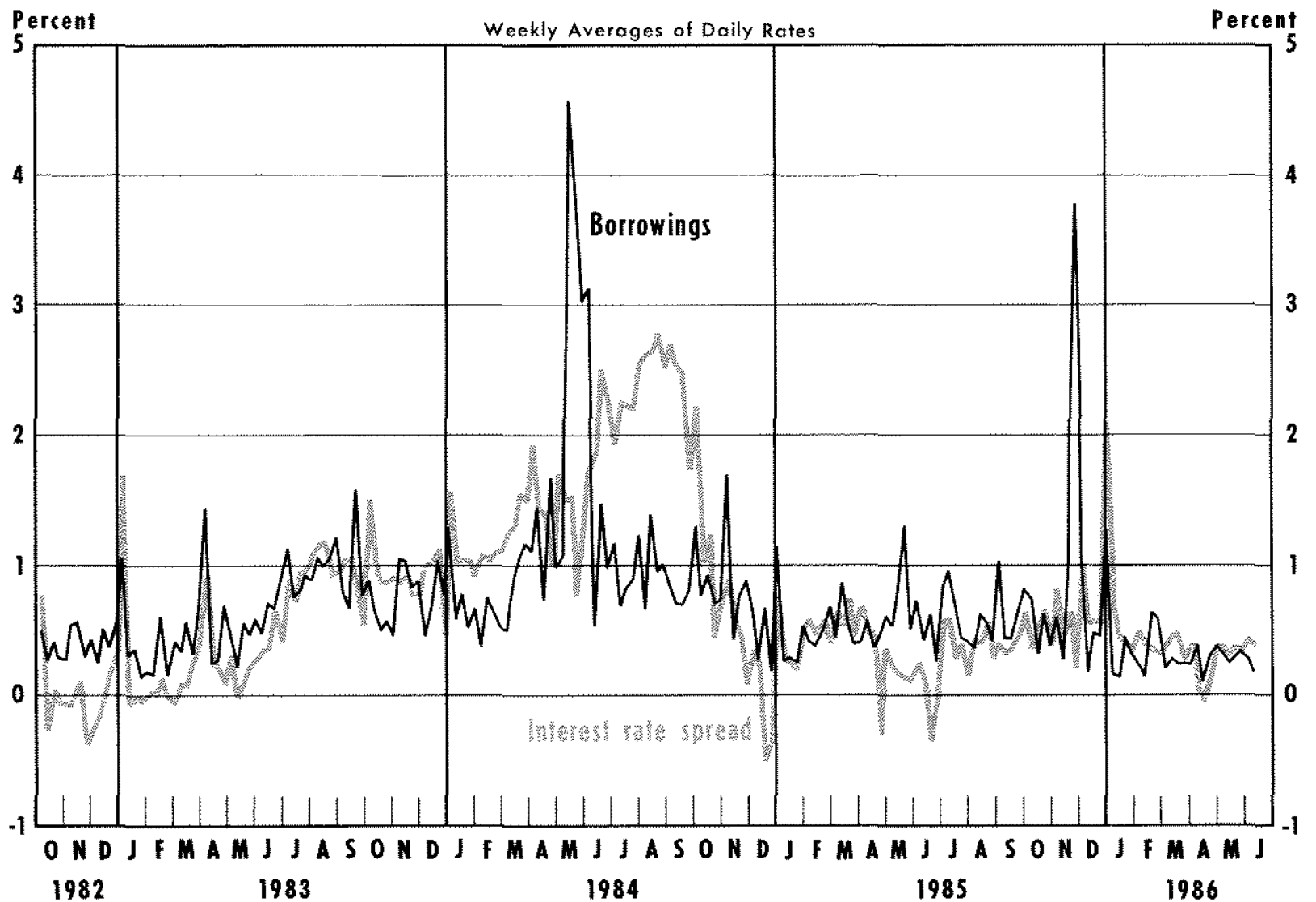

ings and the spread can be estimated statistically by considering the equation:

(3) $\mathrm{BOF}_{1}=\alpha_{4}+\alpha_{i}\left(R_{i}-R_{4}\right)+u_{1}$.

The tem $u$, is a random disturbance that can be thought of as capturing the effect of all factors othes than the rate spread that detemine deviations in borrowing from its average level. From a statistical point of view, the variation in borrowings can be de composed into two sonres: the proportion explained by the rate spread and that explained by all other factors. Since the factors that go into $u_{\text {are }}$ not explictly identified, this is called "unexplained variation.")

Equation 3 is estmated with ondinary least squares, using the weekly data shown in chant 2. The outliers for the weeks ending May 16 to June 6 , 1984, and November 27,1985 , were deleted ${ }^{* 4}$ The results are

${ }^{14}$ If these outliers are not removed, the $\mathrm{R}^{2}$ falls to about .15. presented in the first row of table 1 . The coefficient of determination, denoted $\bar{\Pi}^{2}$, measures the proportion of the variation in borrowings explained by the rate spread, and $1-\overline{\mathrm{R}}^{x}$ is the proportion of variation explained by all other factors. The $\overline{\mathrm{R}}^{2}$ indicates that only 35 pencent of the variation in borrowings is accounted for by the spread, leaving 65 percent to be accounted for by other factors.

The fit can be improved by putting in a dummy variable that takes on the value one for the period from the weok ending June 13, 1984, to October 3,1984 , when the spread was unusually high, and zero elsewhere. The results of including a dummy variable are shown in the second row of table 1. While including the dummy variable boosts the $\overline{\mathrm{F}}^{2}$ somewhat, it does not explain this anomaly. Nevertheless, even after accounting for this apparent shift in the borrowing func: tion, the spread and the dummy variable explain only 
Table 1

\section{Estimates of Equation 3}

\begin{tabular}{ccccc}
\hline Intercept & Dummy variable & Spread & $\overline{\mathbf{R}}^{2}$ & SE \\
\hline $420^{*}$ & & $.291^{*}$ & .35 & .28 \\
$(14.74)$ & $(10.04)$ & & \\
$.368^{*}$ & $-.410^{*}$ & $.419^{*}$ & .40 & .27 \\
$(12.21)$ & $(4.03)$ & $(9.94)$ & & \\
\hline
\end{tabular}

*Indicates the variable is statistically significant at the 5 percent level.

40 percent of the total variation in borrowings, leaving the bulk of the variation to be explained by other factors. ${ }^{\text {ts }}$

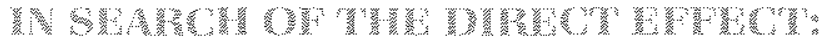

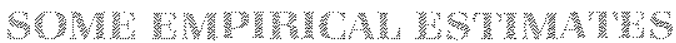

Separating the three possible effects of discount rate changes on market interest rates - the direct, policy and announcement effects - is difficult. The results in table 1, however, provide a basis for estimating the likely direct effect of a discount rate change on interest ates. From the second row of table 1 , we see that a 1 percentagemoint (100 basis-point) decline in the discount rate will cause borrowings to increase by $\$ 419$ billion. All other things the same, this will increase the monetary base (in the form of borowed reserves) by the same amount. Given an M1-monetary base multiplier of 2.7 , this will produce a $\$ 1.13$ billion increase in M1." Such changes in the money stock shift the supply of credit to the right, causing market interest rates to fall. The effect of this on market rates depends on the

\footnotetext{
15Because borrowings fluctuate with market interest rates, they can be a source of cyclical variation in the money stock. Because of this, some have suggested that the discount rate be tied to some makket interes rate. Opponents of this view have argued that no single interest rate adequately represents the appropriate opportunity cost for all institutions. If this were true, rates other than the federal funds rate might explain borrowings. To test this, the second equation on table 1 was reestimated with the difference between the threemonth Treasury bill and federal funds rates added as a separate regressor. The coefficient on the difterence between these rates was not statistically significantly different from zero at the 5 percent level (t-ratio $=-1.26$ ). Hence, it appears that the federal funds rate is the primary interest rate on which borrowing depends.

${ }^{16}$ The $\mathrm{M} 1$ multiplter averaged much less than this during all of the period under consideration, i.e., 2.7 is approxmately its current level
}

extent of the shift in the supply of credit and the interest sensitivity of the demand for credit, so it is possible, in principle, to deternine the effect of an exogenous change in the money stock on interest rates.

The largest estimates of this liquidity effect come from estimated short-run money demand equations. for example, usual estimates suggest that a $\$ 1.13$ billion change in $\mathrm{M} 1$ would produce a 67 basis-point intial change in the three-month Treasury bill rate, but only a six basis-point effect in the long-run equilibrium rate. ${ }^{17}$ is well known, however, that such equations have unreasonably large estimates of the liquid ity effect." Other studies, which attempt to estimate the liquidity effect directly, show only small and transient effects of unanticipated changes in money on interest rates. Using these estimates, a $\$ 1.13$ billion change in the money stock would produce about a one basismoint change in the $T$-bill rate intially, with no long-run effect whatsoever. ${ }^{13}$

Put into another perspective, since October 1982 the aveage, absolute weekly change in $\mathrm{M} 1$ has been $\$ 1.77$ billion, more than one and onemalf times the estimated $\$ 1.13$ billion change in M1 associated with a full 1 percentage-point change in the discount rate. Thus, the direct effect of a change in the discount rate on market interest rates, all other things constant, is likely to be small.

\section{W

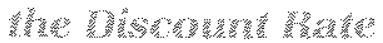

Alternatively, estimates of the magnitude of the direct effect can be obtained by classifying discount rate changes according to the reason they were made. Some discount rate changes are made solely as techncal adjustments, designed to align the discount rate with market interest rates. Others are made for policyrelated reasons. These are called nontechnical changes.

\footnotetext{
7These estimates are based on current levels of $M 1$ and interest fates. Using a short-run interest elasticity estimate from the "nominat-adiustment" specification of the short-run demand for money of -- 015 and a money stock of $\$ 670$ billion, the percentage change in the interest rate would be about 11 percent. A T-bill rate of 6 percent translates into a 67 basis-point change in market interest rates. The long-run effect was calculated under the assumption of a long-run elasticity of about $-.14(-015 / 11)$. These estimates are in line with the results from Thornion (1985).

18 See Carr and Darby (1981)

19 See Brown and Santoni (1983). Similar estimates would be obtained from Cagan and Gandolfi (1969) and Mevin (1983)
} 
Since the response of borrowings to a discount rate change should be the same regardless of the reason for the change, ceteris paribus, the direct effect of a discount rate change on market interest rates should be the same for all changes in the discount rate. Furthermore, there should be no change in the market's perception of policy when discount rate changes are purely technical adjustments. For nontechnical changes, however, not only is there a direct effect due to the impact on bomowings and the supply of credit, but a potential announcement effect, which may or may not be validated by subsequent Federal Reserve actions. If the discount rate changes that are made purely as technical adjustments do not affect market interest rates, this is further evidence that there is essentially no direct effect of discount rate changes. Any interest rate effects come hrough an announcement effect or subsequent policy changes.

It should be noted that the fact that the Fedemal Reserve changes the discount rate from time to time solely to bring it in line with market interest rates is itself prima facie evidence that the link between borrowings and the federal funds/discount rate spread is not the sole determinant of depository institution borrowing. If it were, the Federal Reserve should never have to make such technical adjustments, but this is not the case. Of the nine discount rate changes from October 1982 to June 1986 listed in table $2_{3}$ three were stated to have been made solely for technical reasons and three of the remaining six mentioned technical concems as one of the reasons for the change."

Recent empirical work provides strong evidence that only discount rate changes made for policy reasons affect market interest rates." This work is updated here by estimating the equation:

(4) $\Delta R_{1}=\alpha_{t 1}+\sum_{i=1}^{10} \alpha_{i} \Delta R_{t-i}+\beta \Delta D R_{1}+u_{1}$

${ }^{20}$ This discussion assumes that the Federal Reserve is not trying to control the money stock, and in particular, it is not using a monetary base or total reserves target. If it were, any change in the discount rate would have no direct effect on interest rates because the effect of such a change would be neufralized by compensatory open markel operations.

21The classification used is based upon the Federal Reserve's announced statement of intentions as used by Thornton (1982) and Batten and Thornton (1984, 1985). Smirlock and Yawizz (1985) investigate alternative schemes, but find that the one employed here works best. Their results are supported by Hakkio and Pearce (1986).

22See Thomton (1982), Batten and Thomton (1984, 1985), Smirlock and Yawitz (1985) and Hakkio and Pearce (1986). where $\Delta \mathrm{R}$ denotes the one-day change in a market interest rate, and $\triangle D R$ denotes the change in the discount rate." This equation was estimated using daily data from October 1, 1982, to June 11, 1986, using both the federal funds and three-month Treasury bill rates. The $\mathrm{T}$-bill rate was selected to represent market interest tates in general. Estimates of the coefficient on $\triangle \mathrm{DR}$ and some summary statistics afe presented in table $3^{*}$ The results indicate that a change in the discount rate has a positive, significant effect on both the federal funds and $T$-bill rates on the next market day. The effect on the federal funds rate is roughly 2.5 times that on the $\mathrm{T}$-bill rate.

When the discount rate changes are partitioned into those made for technical reasons ( $\triangle D R T$ ) and those made for nontechnical reasons ( $\triangle D F N T$ ), the results indicate that discount rate changes made solely for technical reasons had no significant effect on the federal funds rate. The results for the T-bill rate are less clear. The coefficient on discount rate changes made solely for technical reasons is smaller than that for policy-related reasons, but is statistically signifcant at the 5 percent level. A closer look, however, reveals that ony one of the three discount rate changes made solely for technical reasons is associated with movement in the " $T$-bill rate in the expected direction. The half-percent decline in the discount rate on October 12,1982 , is associated with a 37 basispoint decline in the $T$-bill rate. In contrast, the halfpercent increase on April 9, 1984, is associated with a 9 basispoint decline in the $T$-bill rate and the halfpercent decrease on April 21, 1986, is associated with no change in the $T$-bill rate.

When discount rate changes made for purely technical reasons are partitioned into the one made on

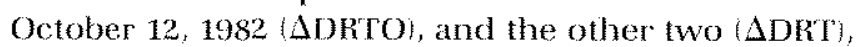
the results indicate that significance of technical changes on the three-month Treasury bill rate is due to the change on October 12. Furthermore, the effect on the federal funds rate is significant at the 10 per-

\footnotetext{
${ }^{23} \Delta D R$ takes on the value of the discount fate change on the day that the change became effective. The one exception is the change that was announced on November 21, 1984, effective immediately. Since the announcement was made at $4: 15$ p.m. EST after the market closed, the $\triangle D R$ takes on a value on November 23 . (The federal funds rate declined by 35 basis points between November 21 and 23 and increased by 4 basis points between November 20 and 21 .

${ }^{24}$ The coefficients on the distributed lag of the dependent variable are not reported because they are intended only to capture the effect of all previously known information on these interest rates and are not of importance themselves.
} 
Table 2

Discount Rate Changes, October 1982 to June 1986

\begin{tabular}{|c|c|c|c|}
\hline Date effective & Change & Classification & Reason \\
\hline October 12,1982 & $10 \%$ to $9.5 \%$ & $T$ & $\begin{array}{l}\text { Action taken to bring the discount rate into closer alignment with short- } \\
\text { term market interest rates }\end{array}$ \\
\hline November 22,1982 & $9.5 \%$ to $9 \%$ & $\mathrm{P}$ & $\begin{array}{l}\text { Action taken against the background of continued progress toward greater } \\
\text { price stability and indications of continued sluggishness in business } \\
\text { activity and relatively strong demand for liquidity }\end{array}$ \\
\hline December 14,1982 & $9 \%$ to $8.5 \%$ & $P$ & $\begin{array}{l}\text { Action taken in light of current business conditions, strong competitive } \\
\text { pressures on prices and further moderation of cost increases, a siowing of } \\
\text { private credit demands and present indications of some tapering off in } \\
\text { growth of the broader monetary aggregates }\end{array}$ \\
\hline April 9,1984 & $8.5 \%$ to $9 \%$ & $T$ & $\begin{array}{l}\text { Action taken to bring discount rate into closer alignment with short-term } \\
\text { interest rates }\end{array}$ \\
\hline Novernber 21,1984 & $9 \%$ to $8.5 \%$ & $P$ & $\begin{array}{l}\text { Action taken now of slow growth of } M \text { and } M 2 \text { and the moderate pace } \\
\text { of business expansion, relatively stable prices and a continued strong } \\
\text { dollar internationally }\end{array}$ \\
\hline December 24,1984 & $8.5 \%$ to $8 \%$ & $\mathrm{P}$ & $\begin{array}{l}\text { Essentialy the same as before plus to bring the discount rate into more } \\
\text { appropriate alghnment with short-term market interest rates }\end{array}$ \\
\hline May 20, 1985 & $8 \%$ to $7.5 \%$ & $P$ & $\begin{array}{l}\text { Action taken in the light of relatively unchanged output in the industry } \\
\text { sector stemming from rising mports and a strong dollar. Rate reduction is } \\
\text { consistent with declining trend in market interest rates }\end{array}$ \\
\hline March 7, 1986 & $7.5 \%$ to $7 \%$ & p & $\begin{array}{l}\text { Action taken in context of simiar action by other important industria } \\
\text { countries and for closer alignment with market interest rates } A \text { further } \\
\text { consideration was a sharp decline in oil prices }\end{array}$ \\
\hline April 21, 1986 & $7 \%$ to $6.5 \%$ & $T$ & $\begin{array}{l}\text { Action taken to bring discount rate into closer alignment with prevaifing } \\
\text { levels of market rates }\end{array}$ \\
\hline
\end{tabular}

$P=$ policy related

$T=$ technical

Source: Federal Reserve Bullefin, paraphrased from statements in various issues, and the Wall Street Joumal.

cent level when these data are partitioned in this way. This is the only instance when a technical change in the discount rate had a significant effect on market rates. The preponderance of evidence suggests that discount rate changes made solely for technical reasons have no statistically significant effect on market interest rates." This result is consistent with our pre-

\footnotetext{
25 This change was announced two days after the Federal Reserve deemphasized $M-1$ as a monetary target. (See Thomton (1983) for a discussion of this period.) While there was no immediate announcement of the decision to de-emphasize M1, there were leaks to this effect, so the market may have interpreted the October 12 decrease in the discount rate as an indication that the Federal Reserve woutd move toward an easier policy. There were leaks to the press on October 7 that the Federal Reserve would pay more attention to interest rates and less to $M 1$ growth. See BNA's Daily Report for Executives, October 8, 1982.

${ }^{26}$ This finding has been reiterated by Thomton (1982), Smirtock and Yawizz (1985) and the results presented in lable 5 for the money
}

vious finding that there is little, if any, direct effect of a discount mate change on market interest rates.

It could be, however, that discount rate changes made solely for technical reasons are more readily anticipated than those made for policy reasons ${ }^{2 T}$ If this were the case, and if the market perceived the effect of the corresponding change in the money supply on interest rates, maket ates would change prior to the change in the discount rate so there would be no statisticaly significant eftect following the announcement of a discount rate change. Hakkio and Pearce (1986) report that discount rate changes made for technical reasons are no more readily forecasted than those made for nontednical reasons. Hence, this

market, and by Batten and Thornton $(1984,1985)$ and Hakkio and Pearce (1986) for the foreign exchange market.

${ }^{27}$ This conjecture is offered by Batten and Thornton (1984). 
Table 3

\section{Estimates of Equation 4 for Technical and Nontechnical Discount Rate Changes}

\begin{tabular}{|c|c|c|c|c|c|c|}
\hline Constant & $\Delta \mathrm{DR}$ & $\triangle \mathrm{DRNT}$ & $\triangle D R T$ & $\triangle$ DRTO & $\overrightarrow{\mathbf{R}}^{2}$ & SE \\
\hline \multicolumn{7}{|c|}{ Federal funds rate } \\
\hline $\begin{array}{r}-.011 \\
(0.94)\end{array}$ & $\begin{array}{c}.690^{*} \\
(2.95)^{2}\end{array}$ & & & & .20 & .35 \\
\hline $\begin{array}{c}-.010 \\
(0.91)\end{array}$ & & $\begin{array}{c}.827^{*} \\
(2.90)\end{array}$ & $\begin{array}{c}.412 \\
(1.02)\end{array}$ & & .20 & .35 \\
\hline $\begin{array}{c}-.010 \\
(0.87)\end{array}$ & & $\begin{array}{c}.829^{\star} \\
(2.91)\end{array}$ & $\begin{array}{r}-.009 \\
(0.02)\end{array}$ & $\begin{array}{r}1.289 \\
(1.81)\end{array}$ & .20 & .35 \\
\hline \multicolumn{7}{|c|}{ Treasury bill rate } \\
\hline $\begin{array}{c}-.000 \\
(0.12)\end{array}$ & $\begin{array}{c}.267^{*} \\
(4.74)\end{array}$ & & & & .03 & .08 \\
\hline $\begin{array}{l}-.000 \\
(0.10)\end{array}$ & & $\begin{array}{c}.299^{\star} \\
(4.32)\end{array}$ & $\begin{array}{c}.204^{*} \\
(2.08)\end{array}$ & & .03 & .08 \\
\hline $\begin{array}{r}.000 \\
(0.02)\end{array}$ & & $\begin{array}{c}.297^{\star} \\
(4.33)\end{array}$ & $\begin{array}{c}-.066 \\
(0.56)\end{array}$ & $\begin{array}{c}.789^{*} \\
(4.55)\end{array}$ & .04 & .08 \\
\hline
\end{tabular}

${ }^{\star}$ Indicates statistical significance at the 5 percent level.

alternative interpretation appeass to have little merit

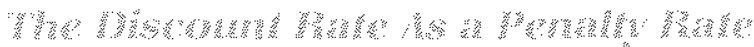

Another way of estimating the direct effect of a discount rate change on market interest rates comes from noting that depository institutions have little incentive to borrow from the Federal Reserve when the discount rate is a "penalty rate," that is, when it is above the federal funds mate. Depository institutions that borrow from the Federal Reserve when the discount rate is a penalty rate are assumed to do so for reasons other than to minimize the explicit cost of obtaining resenve-adjustment funds. Changes in the discount rate that come when the discount rate is a penalty mate - especially changes that leave the discount mate at penaly levels - should have no effect on borrowing and hence, no direct effect on maket interest rates: If estimates indicate that discount rate

\footnotetext{
2aTheir "forecasts," however, are based on in-sample results and are nol true ex ante forecasts.

${ }^{29}$ White this idea is common in the literafure, e.g., Broaddus and Cook (1983) and Sellon and Seiber (1982), if is sometimes presented in such a way that if appears that the only effect is the direct effect. In this case, any finding of a significant effect of a discount rate change on market interest rates mplies that is is produced via the direct effect. We have shown, however, this is not the case.
}

changes made when the discount rate is not a penalty rate do not have an effect on maket rates, while those made when the discount late is a penalty rate do have a significant effect, this would be further evidence that there is no direct effect of a discount rate change on market interest rates.

To test this hypothesis, discount rate changes were partitioned into those when the discount rate was a penalty mie ( $\triangle D R P$ ) prios to the announcement and those when the discount rate was not a penalty rate (DDRNP): The results, reported in table 4 , indicate that changes made when the discount rate was a penaly rate are statistically significant ${ }^{3 \mathrm{~F}}$ Furthemore,

\footnotetext{
30The partition used was based upon whether the discount rate was a penalty rate with respect to the federal funds rate. There was only one instance when the discount rate was a penalty with respect to the $T$-bill rate. Such a partition is of little interest, however, since the evidence in footnote 15 indicates that the federal funds rate is the relevant opportunity cost variable.

"Sellon and Seibert (1982) performed a similar anclysis on data for the period from February 1980 to August 1982 and found that discount rale changes made when the discount rate was a penalty rate had no statistically significant effect on market interest rates or borrowings. During this period, however, such discount rate changes were primarily those made for technical reasons; thus it appears that the Sellon and Seibert result is due to this fact and not to the fact that the discount rate was at a penaity level at the time of the change. See Thomton (1982) for the technical vs. nontechnical results over a similar period.
} 
changes made when the discoun rate was not a penalty rate were not statistically significant. These results are precisely the opposite of those that should have been obtained if the effect of a discount rate change, reported in table 3 , were due to a direct effect.

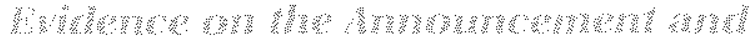

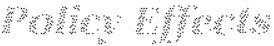

The evidence indicates that discount rate changes do not directly affect market interest rates. Conse quently, the effect on market rates indicated in table 3 must be due to an announcement effect, a policy effect or both. Because the effect measured in table 3 occurs on the day following the announcement of a change in the discount rate and changes made for technical reasons have no effect on market mates, thes strongly suggests that it is, at least in part, an announcement effect. It is impossible to determine, however, whether the expectations were subsequently validated by changes in the rate at which the Federal Reserve supplied reserves. 3

Attempts made to test directly for a policy response following a discount rate change were inconclusive. Nevertheless, some evidence bears on the policy effect, at least in terms of its implications for the period following the October 1982 change in the Federal Reserve's operating procedure. First, if the Fed's new operating procedure attempts to maintain a constant spread between the federal funds and discount rate, borrowings always should be close to their assumed level. Chart 3 plots the actual level of adjustment plus seasonal borrowings and their assumed level for weekly data from October 6, 1982, through December 1985. As the chart shows, the actual level of borrowing often deviates from the initial bomrowing assumption,

\footnotetext{
${ }^{32}$ Alternatively, Smirlock and Yawitz (1985) allow for the change in the discount rate to impact market interest rates with a lag of up to five days. Because they cannot reject the hypothesis that effects past the inital day are significant, they conclude that the rapid adjustment is consistent with market efficiency. Because the marke: rates nearly always return to levels prior to discount rate changes, however, it is possible to find no statistically significant long-run effect simply by making the lag "long enough" of a permanent effect (as they found) by making it "short enough."

${ }^{3}$ Several attempts to directly lest various hypotheses were conducted, but the results were unsatisfactory. For example, discount rate changes that indicate a change in policy - regardless of the reason given for the change - should be followed by a sharp change in the growth of nonborrowed reserves. Hence, statistical tests of nonborrowed reserve growth before and after discount rate changes were undertaken. Because the nonborrowed reserve data only are available biweekly, the tests were also done using weekly Mt data. The results indicated no statisticaly significant change in the growth rate of either nonborrowed reserves or $M$; however, the data were highly variable and the observations few. Hence, these tests should be considered inconclusive.
}

Table 4

Estimates of Equation 4 for Penalty and Non-Penalty Discount Rate Changes

\begin{tabular}{|c|c|c|c|c|}
\hline Constant & $\triangle D R P$ & $\triangle \mathrm{DRNP}$ & $\overline{\mathbf{A}}^{2}$ & SE \\
\hline \multicolumn{5}{|c|}{ Federal funds rate } \\
\hline $\begin{array}{r}-010 \\
(0.93)\end{array}$ & $\begin{array}{r}.741^{*} \\
(2.58)\end{array}$ & $\begin{array}{r}588 \\
(1.46)\end{array}$ & 20 & .35 \\
\hline \multicolumn{5}{|c|}{ Treasury bill rate } \\
\hline $\begin{array}{r}-000 \\
(0.04)\end{array}$ & $\begin{array}{r}.372^{\star} \\
(5.41)\end{array}$ & $\begin{array}{r}.060 \\
(0.62)\end{array}$ & .03 & .08 \\
\hline
\end{tabular}

Indicates statistical significance at the 5 percent level:

sometimes by a considerable magnitude. Two of the most notable deviations, of course, occurred in mid1984 and November 1985. Even when these unusual periods are ignored, the average absolute deviation of bofrowings from the initial bofrowing assumption is $\$ 226$ million, over 40 percent of the avemage level of the initial borrowing assumption during the period.

Furthermore, there is a tendency for the initial borrowing assumption to follow, rather than lead, changes in actual borrowings. It appears that the federal funds/discount rate spread is maintained when the borrowing assumption changes; the demand for borrowed reserves is not forced to conform to the bomowing assumption.

Second, if the policy effect is strong, the response of market interest rates, especially the federal funds rate, to a change in the discount rate should be larger since the October 1982 change in the operating procedure. To test this, equation 4 was reestimated for the period from October 1, 1979, to June 11, 1986, and the response of market interest mates to nontechnical changes in the discount rate was allowed to be different for the periods October 1, 1979, to October 5, 1982, and Oetober 6,1982 , to June 11,1986 . The results are reported in table 5 with the coefficients for the preand post-October 1982 periods denoted by $\triangle$ ORNTPRE 82 and $\triangle$ DRNTPOST82, respectively ${ }^{34}$

\footnotetext{
Because of the differences in the variation of the dependent variables between the periods, the equation was estimated adjusting for heteroskedasticity. Also, the pre-October 1982 period includes a surcharge variable because Thornton (1982) has shown the results are sensitive to this modification. While not reported here, the surcharge coefficient is nearly identical to that reported by Thornton. The coefficient on $\triangle D A N T P R E 82$ differs from that reported by Thornton primarily because of a difference in the sample period; however, all of the qualitative conclusions are the same.
} 


\section{Chart 3}

\section{Adjustment plus Seasonal Borrowings from Federal Reserve and Initial Borrowing Assumption}

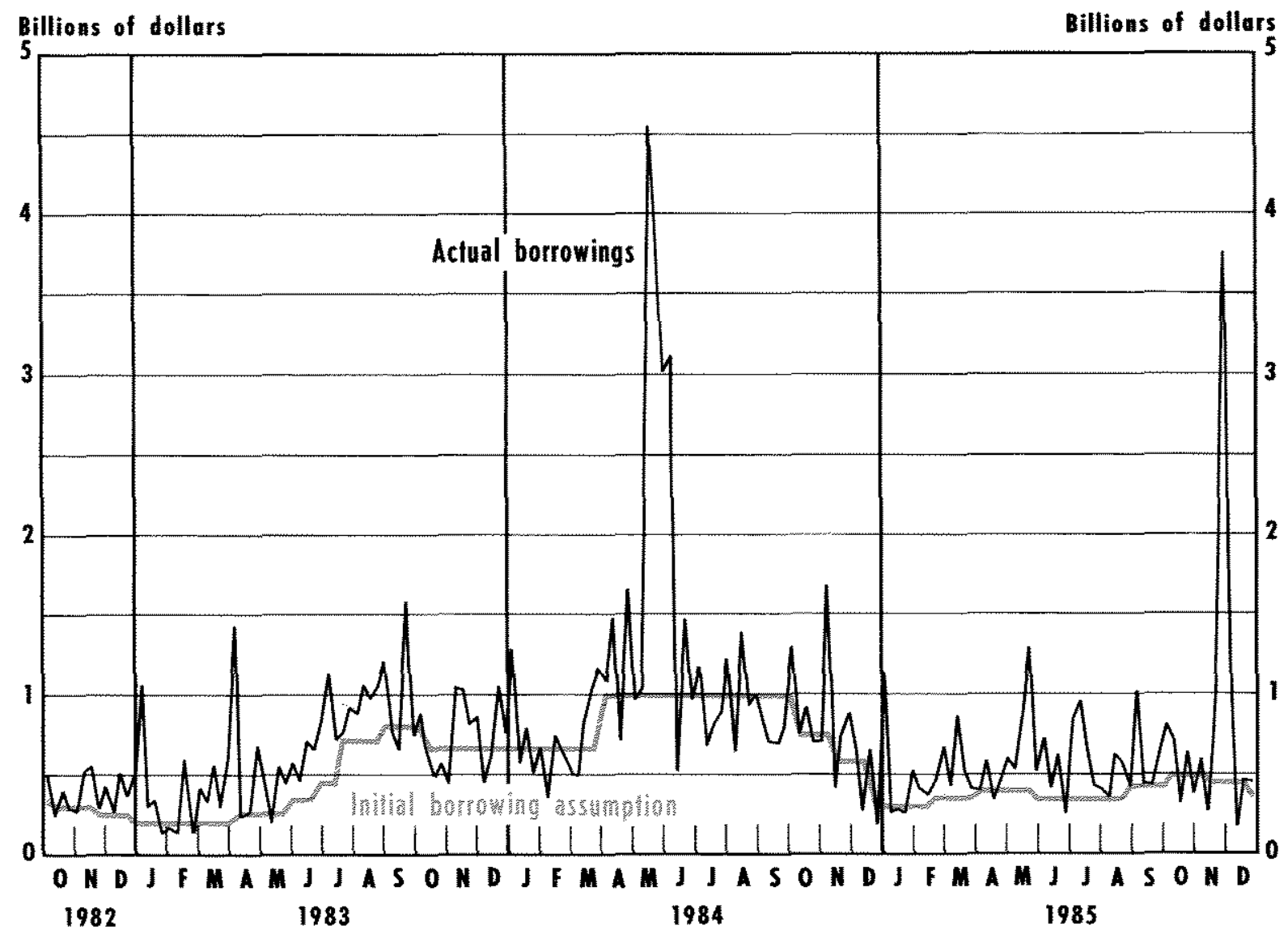

The results show that the responsiveness of the federal funds rate to changes in the discount rate was essentialy the same during the two periods. Indeed, an F-lest of the equality of the Iwo coefficients does not reject the hypothesis that the response was the same. There is a statistically significant difference in the responsiveness of the ' $T$-bill rate; however; it has become less, not more, responsive to changes in the discount rate. The evidence suggests that the shift in the Fed's operating procedure has not increased the initial response of market interest rates to discount rate changes; if anything il appears to have lowered it.

Finally, there is one additional piece of evidence on the announcement vs, policy effect of a discount rate change. The effect of the discount rate on maket interest rates, especially the policy effect, implies causality running from the federal funds rate to other market interest rates. In order to investigate this, tests of "Granger causality" were conducted using both daily and weekly data for the fedoral funds and threemonth Treasury bill nates. These tests are designed to determine whether changes in one rate precede or follow changes in the other. (Details and results are presented in the appendix. The results using the daily data indicate that changes in the Thill rate precede changes in the lederal funds, the reverse of what the policy-effect hypothesis would most strongly imply. The results using weekly data are less definitive, indicating that at times either rate precedes the other. White this result is not particularly surprising, the fact that the stronger (most statistically significant) effect is from the $T$-bill rate to the federal funds rate is inconsistent with a strong policy effect.

While these results are disquieting to those who support the policy effect, they are not conclusive. The importance one assigns to the announcement or pol- 


\section{Table 5}

\section{Estimates of Equation 4 with the Discount Rate Partitioned into the Pre-and Post-October 1982 Periods}

\begin{tabular}{|c|c|c|c|c|c|c|c|}
\hline $\begin{array}{l}\text { Dependent } \\
\text { Varable }\end{array}$ & onstant & $\triangle \mathrm{DFT}$ & $\triangle \mathrm{DHNTPFEB2}$ & ADRKIPOSTR2 & ETest & $\overline{12}$ & SE \\
\hline Pederal tunds rate & $\begin{array}{l}006 \\
1054)\end{array}$ & $\begin{array}{r}382 \\
(139)\end{array}$ & 824 & $27)^{\star}$ & 013 & 14 & 101 \\
\hline Treasury bill tate & $\begin{array}{l}-001 \\
(0,23)\end{array}$ & $\begin{array}{l}128 \\
(188)\end{array}$ & $\begin{array}{l}686 \\
(6,57)\end{array}$ & $\begin{array}{l}292^{*} \\
(4,43)\end{array}$ & $10,200^{*}$ & 04 & 100 \\
\hline
\end{tabular}

7 indicates statistical significance at he 5 percent level.

Test of the hypothes that he coefficients on $\triangle \mathrm{DPNTPRE} 82$ and $\triangle \mathrm{DPNTPOST} 82$ are equal

icy effects depends on the interpretation of a discount rate change. If it is believed that discount rate changes are primarily signals that the federal Reserve is going to continue its present policy of ease or restraint, the policy effect should be nil. If, on the other hand, discount rate changes typically signal a change in the rate at which the Federal Reserve is going to supply reserves to the system, the extent to which one believes this change will affect market interest rates depends on one's view of the liquidity effect. If the liquidity effect is believed to be weak and transient as most empirical work suggests - the response of the market to such changes is essentially noise, with no real significance for the future course (or level) of market interest rates. In such instances, discount rate cuts that are followed by more expansionaty monetary policy ultimately might be followed by higher, not lower, interest sates if such a policy change gives rise to expectations of higher inflation. On the other hand, if one believes that the liquidity effect is strong and lasting, changes in the discount wate will be thought to have permanent effects on market interest rates, but only if followed by a change in Federal Reserve policy.

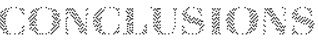

This article was intended to clarify the relationship between the Federal Reserve's discount rate and market interest rates. Three distinct, though not mutually exclusive, potential effects of a discount rate change on market interest rates were outlined: 11 the "direct, ceteris paribus, effect," which abstracts from market reactions to the discount tate change and any subsequent change in Federal Reserve operations; (2) the "announcement effect," which reflects the changing expectations of the Federal Reserve's activity based on the announced change in the discount rate; and (3) the "policy effect," the impact of a subsequent change in Federal Reserve activity on the market. Special attention was given to the hypothesis that the impact of discount rate changes on market interest rates became stronger following the Federal Reserve's switch from a nonborrowed reserve to a borrowed reserve operating procedure in October 1982.

The evidence showed a statistically significant effect of a change in the discount rate on both the federal funds and Treasury bill rates immediately following the discount rate change. A series of tests provided evidence, consistent with the theory, that the direct effect of a discount rate change is nil. Consequently, the impact of a discount rate change on mafket rates is due to an announcement effect, a policy effect or both. The rapidity with which market rates respond to the discount rate change suggests that the announcement effect is operative. Furthermore, some indirect tests of the policy effect produced results that are inconsistent with it, suggesting that discount rate changes have had no permanent effect on market interest rates.

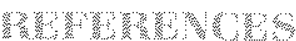

Batten, Dallas S., and Daniel L. Thomton. "Discount Rate Changes and the Foreign Exchange Market," Joumal of International Money and Finance (December 1984), pp. $279-92$.

"The Discount Rate, Interest Rates and Foreign Ex. change Rates: An Analysis with Daily Data," this Review (February 1985), pp. 22-30.

Broaddus, Altred, and Timothy Cook. "The Relationship Between the Discount Rate and the Federal Funds Rate Under the Federal Reserve's Post-October 6, 1979 Operating Procedure," Federal Reserve Bank of Richmond Economic Review (January/February 1983). pp. 12-15. 
Brown, W. W., and G. J. Santoni. "Monetary Growth and the Iiming of interest Rate Movements," this Review (AugustSeptember 1983), pp. 16-25.

Cagan, Phillip, and Arthur Gandolfi. "The Lag in Monetary Policy as Implied by the Time Pattern of Monetary Effects on Interest Rates," American Economic Review (May 1969), pp. 277--84.

Carr, Jack, and Michael R. Darby. "The Role of Money Supply Shocks in the Short-Run Demand for Money, "Joumal of Monetary Economics (September 1981), pp. $183-99$.

Cukierman, Alex. "Central Bank Behavior and Credibility: Some Recent Theoretical Developments," this Review (May 1986), pp. 5-17.

Daily Report for Executives, The Bureau of National Affars, Inc., Washington (October 8,1982 ), L12.

Federal Reserve Bank of New York. "Monetary Policy and Open Market Operations in 1985," Quarterly Review (Spring 1986). pp. 34-53.

Hakkio, Craig S., and Douglas K. Pearce. "Exchange Rates and Discount Rate Changes," Federal Reserve Bank of Kansas City working paper 86-06 (1986)

Melvin, Michael. "The Vanishing Liquidity Effect of Money on Interest: Analysis and Implications for Policy," Economic Inquiry (April 1983), pp. 188-202

Partian, John C., Kausar Hamdani, and Kathleen Camilli. "Reserves Forecasting for Open Market Operations," Federal Reserve Bank of New York Quanterly Review (Spring 1986), pp. 19 33.
Rotey, V. Vance. "Market Perceptions of U.S. Monetary Policy Since 1982," Federal Reserve Bank of Kansas City Economic Review (May 1986), pp. 27-40.

Sellon, Gordon H., and Diane Seibert. "The Discount Rate: Experience Under Reserve Targeting. "Federal Reserve Bank of Kansas City Economic Review (September-October 1982), pp. 3-18.

Smirlock, Michael, and Jess Yawitz. "Asset Returns, Discount Rate Changes, and Market Efficiency," The Journal of Finance (Septem. ber 1985), pp. 1,141-158.

Smith, Warren $L$. "The Instruments of General Monetary Control," National Bank Review (September 1963), pp. 47-76.

Thomton, Daniel L. "The Discount Pate and Market Interest Rates: What's the Connection?" this Review (June/July 1982), pp. 3-14.

"The FOMC in 1982: De-emphasizing M1," this Review (June/July t983) pp. 26-35.

"Money Demand Dynamics: Some New Evidence," this Review (March 1985), pp. 14-23

Thornton, Daniel L., and Dallas S. Batten. "Lag-Length Selection and Tests of Granger Causality Between Money and Income, Joumal of Money, Credit and Banking (May 1985), pp. 164-78.

Wallich, Henry C. "Recent Techniques of Monetary Policy," Federal Reserve Bank of Kansas City Economic Review (May 1984), pp. $21-30$.

(See appendix on nexl page.) 


\section{Avery}

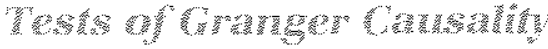

Tests of "Granger causality" are really tests of temporal ordering of time series. The test of catusality running from the federal funds rate to the Treasury bill rate is performed by estimating, using ordinaty least squares (OLS), the equation

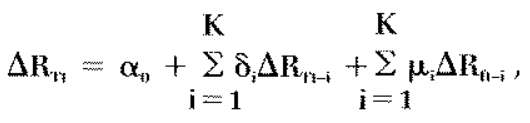

where $\Delta$ denotes the first difference operator, i.e., $\Delta R_{12}$ $=\mathbf{R}_{\mathrm{fi}}-\mathbf{R}_{\mathrm{it}-\mathrm{k}}$, and $\mathbf{R}_{\mathrm{r}}$ and $\mathbf{R}_{\mathrm{q}}$ denote the federal funds and three-month Teasury bill rates, respectively. The procedure consists of testing the hypothesis that $\mu_{1}=\mu_{3}$ $=\ldots=\mu_{k}=0$. If this hypothesis is rejected, it is said the "causality" runs from the fedenal funds rate $\left(R_{i}\right)$ to the three-month Treasury bill rate $\left(\mathbf{R}_{q}\right)$. To test for causality running from the Treasury bill rate to the federal funds rate, the equation

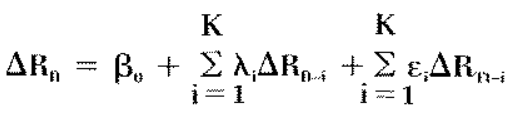

Table A.1

Granger Causality Results for $\Delta \mathbf{R}_{\mathrm{r}}$ and $\Delta \mathbf{R}_{\mathrm{r}}$ : Daily Data

\begin{tabular}{|c|c|c|c|c|c|c|c|c|c|c|c|c|}
\hline \multirow{2}{*}{$\begin{array}{ll}\mathrm{ags} \\
\mathrm{Al}\end{array}$} & \multicolumn{12}{|c|}{ Tests of $\mathrm{s} s=0$} \\
\hline & 1 & 2 & 3 & 4 & 5 & 6 & 7 & 8 & 9 & 10 & 11 & 12 \\
\hline 1 & 342 & 355 & 358 & 382 & 377 & 378 & 346 & 346 & 338 & 342 & 342 & 341 \\
\hline 2 & 624 & 610 & 616 & 646 & 646 & 647 & 583 & 585 & 575 & 586 & 587 & 585 \\
\hline 3 & 570 & 524 & 481 & 519 & 526 & 527 & 486 & 497 & 498 & 512 & 513 & 512 \\
\hline 4 & 678 & 647 & 617 & 67 & 681 & 682 & 651 & 662 & 660 & 675 & 675 & 675 \\
\hline 5 & 775 & 139 & 707 & 741 & 715 & 716 & 672 & 685 & 683 & 675 & 676 & 675 \\
\hline 6 & 707 & 682 & 666 & 713 & 709 & 704 & 695 & 704 & 694 & 686 & 686 & 684 \\
\hline 7 & 718 & 706 & 696 & 751 & 754 & 746 & 650 & 653 & 634 & 645 & 646 & 639 \\
\hline 8 & 494 & 480 & 457 & 492 & 473 & 471 & 462 & 436 & 439 & 428 & 429 & 423 \\
\hline 9 & 339 & 325 & 305 & 311 & 291 & 292 & 317 & 284 & 246 & 218 & 218 & 219 \\
\hline 10 & 267 & 242 & 223 & 223 & 197 & 198 & 250 & 216 & 171 & .185 & 184 & .186 \\
\hline 11 & 238 & 227 & 217 & 220 & 198 & 199 & 237 & 213 & 178 & 178 & .172 & .172 \\
\hline 12 & 211 & 208 & 205 & 218 & 199 & 200 & 217 & 199 & 176 & 168 & 159 & 163 \\
\hline \multicolumn{13}{|c|}{ Tests of $e^{\prime} s=0$} \\
\hline \multicolumn{13}{|c|}{ Lags of $\Delta \mathrm{n}_{\mathrm{f}}$} \\
\hline Lags of & & & & & & & & & & & & \\
\hline$\Delta \mathrm{R}_{\mathrm{i}}$ & 1 & 2 & 3 & 4 & 5 & 6 & 7 & 8 & 9 & 10 & 11 & 12 \\
\hline 1 & .681 & .379 & 304 & 195 & .173 & .107 & .102 & .098 & .059 & .061 & .057 & .060 \\
\hline 2 & .837 & .581 & 419 & .249 & .167 & .097 & .054 & $.050^{*}$ & $.03 t^{*}$ & $.032^{*}$ & $.026^{*}$ & $.026^{*}$ \\
\hline 3 & .597 & .372 & 469 & .386 & .300 & 198 & .117 & .106 & .068 & .070 & .058 & .055 \\
\hline 4 & .640 & .409 & .462 & .540 & .453 & .310 & .166 & .147 & .084 & .087 & .071 & .064 \\
\hline 5 & .524 & .288 & .302 & .293 & .437 & .397 & .256 & .235 & .145 & .149 & .125 & .114 \\
\hline 6 & .625 & .382 & .385 & .360 & .474 & .524 & .338 & .303 & .174 & .178 &.$\$ 46$ & .132 \\
\hline 7 & .673 & .476 & .480 & .466 & .590 & .639 & .377 & .315 & 166 & .168 & .135 & .116 \\
\hline 8 & .686 & .526 & .552 & .540 & .676 & .733 & .482 & .408 & .220 & .222 & .177 & .152 \\
\hline 9 & .770 & .620 & .648 & .641 & .765 & .809 & .563 & .477 & 299 & 301 & .246 & .213 \\
\hline 10 & .792 & .634 & .654 & .659 & .799 & .835 & .638 & .560 & .381 & .382 & .317 & .276 \\
\hline 11 & .850 & .714 & .734 & .740 & .859 & .878 & .707 & .627 & .435 & .434 & .381 & .343 \\
\hline 12 & .787 & .633 & 649 & 628 & .745 & .777 & .658 & .579 & .424 & .425 & .384 & .319 \\
\hline
\end{tabular}

"Indicates significance at the 5 percent level. 
Table A.2

Granger Causality Results for $\Delta \mathbf{R}_{\mathrm{t}}$ and $\Delta \mathbf{R}_{\mathrm{T}}$ : Weekly Data

\begin{tabular}{|c|c|c|c|c|c|c|c|c|c|c|c|c|}
\hline \multirow{3}{*}{$\begin{array}{c}\text { Lags of } \\
\Delta A\end{array}$} & \multicolumn{12}{|c|}{ Tests of $\mu^{\prime} s=0$} \\
\hline & \multicolumn{12}{|c|}{ Lags of $\Delta R_{7}$} \\
\hline & 1 & 2 & 3 & 4 & 5 & 6 & 7 & 8 & 9 & 10 & 11 & 12 \\
\hline 1 & 269 & .258 & .242 & .314 & .319 & .312 & $.36 t$ & .415 & .352 & .339 & .341 & 434 \\
\hline 2 & 538 & .505 & 493 & .580 & .570 & .564 & .615 & .673 & .649 & .632 & .635 & .736 \\
\hline 3 & .291 & .337 & 423 & .466 & 477 & .453 & .501 & .536 & .567 & .482 & 485 & .525 \\
\hline 4 & .325 & .374 & .512 & .602 & 613 & .584 & .617 & .648 & .677 & .607 & .606 & 632 \\
\hline 5 & .209 & .248 & .352 & .501 & .535 & $\therefore 531$ & .549 & .590 & .648 & 593 & .596 & 544 \\
\hline 6 & $.025^{\pi}$ & $.031 \%$ & .053 & .086 & 086 & .051 & .066 & .077 & .058 & .056 & .057 & .058 \\
\hline 7 & $.028^{\circ}$ & 034 & .056 & .084 & 085 & 066 & .092 & 108 & .085 & .085 & .087 & .087 \\
\hline 8 & $038^{*}$ & $047^{\star}$ & 077 & 113 & 112 & 088 & 108 & 131 & .117 & 116 & 118 & 118 \\
\hline 9 & 061 & 074 & 115 & 162 & 161 & 130 & 158 & 187 & 162 & 164 & 166 & 161 \\
\hline 10 & 074 & 088 & 136 & 169 & 170 & 147 & 185 & 216 & 225 & 225 & 228 & 221 \\
\hline 11 & 092 & 109 & 161 & 205 & 210 & 192 & 241 & 275 & 293 & 297 & 299 & 292 \\
\hline 12 & .099 & 117 & 170 & 215 & 209 & 207 & 265 & 294 & 346 & 356 & 361 & 370 \\
\hline \multicolumn{13}{|c|}{ Tests of ${ }^{\prime} s=0$} \\
\hline \multicolumn{13}{|c|}{100} \\
\hline Lags of & & & & & & & & & & & & \\
\hline$\Delta \mathrm{R}_{7}$ & 1 & 2 & 3 & 4 & 5 & 6 & 7 & 8 & 9 & 10 & 11 & 12 \\
\hline 1 & 073 & 031 & $022^{*}$ & $039^{x}$ & 041 & $038^{x}$ & $046^{*}$ & 041 & 046 & $045^{x}$ & $042^{*}$ & 054 \\
\hline 2 & 181 & 007 & 070 & 115 & 123 & 115 & 134 & 123 & 137 & 136 & 128 & 157 \\
\hline 3 & $043^{*}$ & $029 *$ & $008 t$ & 021 & 024 & $020^{*}$ & $024^{*}$ & $029^{n}$ & 080 & 078 & 077 & 087 \\
\hline 4 & $027^{*}$ & $016^{*}$ & $005^{\star}$ & $015^{*}$ & $018^{\circ}$ & $015^{*}$ & $017^{*}$ & $022^{-}$ & 069 & 071 & 065 & 071 \\
\hline 5 & $045^{\circ}$ & $024^{*}$ & $007^{*}$ & 018 & 021 & $015^{\circ}$ & $017^{\circ}$ & $022^{\star}$ & 063 & 065 & 066 & 111 \\
\hline 6 & $040^{\circ}$ & $022^{\star}$ & $009^{\circ}$ & 021 & $024^{\circ}$ & $021^{\circ}$ & $024^{\circ}$ & $.030^{*}$ & 071 & 073 & 067 & 167 \\
\hline 7 & $.045^{\circ}$ & $027^{\circ}$ & $012^{*}$ & $027^{\circ}$ & $.031^{\circ}$ & 028 & $032^{*}$ & $.044^{*}$ & 103 & 107 & .103 & .161 \\
\hline 8 & $027^{\circ}$ & $017^{\circ}$ & $.007^{*}$ & $017^{*}$ & $018^{\circ}$ & $.016^{*}$ & $019^{\circ}$ & $.029^{\circ}$ & 101 & .104 & 107 & .103 \\
\hline 9 & $044^{*}$ & $.027^{*}$ & $.013^{*}$ & $028^{\circ}$ & $.030^{*}$ & $.027^{\star}$ & $.030^{*}$ & $.045^{\circ}$ & .149 & .153 & .158 & .138 \\
\hline 10 & .062 & $.036^{*}$ & $.014^{*}$ & $.030^{\circ}$ & $.033^{\star}$ & $.030^{*}$ & $.034^{*}$ & $.049^{*}$ & .144 & 141 & .157 & 108 \\
\hline 11 & $.044^{*}$ & $.028^{*}$ & $.013^{*}$ & $.026^{\circ}$ & $.027^{*}$ & $.025^{*}$ & $.028^{*}$ & $.041^{*}$ & .115 & .109 & .110 & .146 \\
\hline 12 & .063 & $.041^{*}$ & $.020^{*}$ & $.038^{\star}$ & $.041^{\dot{*}}$ & $.037^{*}$ & $.042^{\star}$ & .059 & .150 & .143 & .146 & .183 \\
\hline
\end{tabular}

"Indicates significance at the 5 percent level.

is estimated and the hypothesis that $\varepsilon_{1}=\varepsilon_{3}=\ldots=\varepsilon_{\mathrm{k}}$ $=0$ is tested. If the hypothesis is rejected, the causality runs from the Treasury bill mate to the federal funds rate. If the hypotheses conceming the $\mu$ 's and the $\varepsilon$ 's are both rejected, there is said to be bidirectional catusality between the rates. If neither is rejected, the series are said to be independent.

The tests were performed using both daly and weekly data. Because the test results are quite sensifive to the order of the $\mathrm{lag}, \mathrm{K}$, the tests were performed on all onders up to $K=12$.' The significance levels

'For a discussion of this procedure, see Thornton and Batten (1985). corresponding to the F-statistics for all onders are presented in tables A.t and A.2 for the daily and weekly data, respectively.

The tests using daily data show unidirectional causality from $R_{3}$ to $R_{1}$, the opposite of what is required for policy actions to be transmitted from the federal funds rate to other market interest rates. It should be noted that the daily federal funds mate series exhibits considerably more variability than the $T$-bill rate series. When these data are smoothed by averaging over a week, the tests indicate bidirectional causality; however, the stronger felationship appears to be running from the T-bill rate to the federal funds rate. 